\title{
A COMPARATIVE STUDY OF PRUDENTIAL REGULATION ON LOAN CLASSIFICATION AND PROVISIONING OF THE SOUTH EAST EUROPEAN COUNTRIES
}

\author{
Albulena Shala ${ }^{1}$, Hysen Ismajli ${ }^{1}$, Rezearta Perri $^{2}$ \\ ${ }^{1}$ Department of Bank, Finance and Accounting, Faculty of Economics, University of Prishtina "Hasan Prishtina", \\ 10000 Prishtina, Republic of Kosovo \\ ${ }^{2}$ Department of Accounting, Faculty of Economics, University of Tirana, Tirana 11215, Albania
}

To cite this article: SHALA ALBULENA, ISMAJLI HYSEN, PERRI REZEARTA. 2018. A Comparative Study of Prudential Regulation on Loan Classification and Provisioning of the South East European Countries. Acta Universitatis Agriculturae et Silviculturae Mendelianae Brunensis, 66(5): 1337-1346.

To link to this article: https://doi.org/10.11118/actaun201866051337

\begin{abstract}
This paper has been prepared to describe the regulatory measures regarding Loan classification and provisioning of South East Europe countries like Albania, Bosnia and Herzegovina, Bulgaria, Croatia, Kosovo, Macedonia, Montenegro, Serbia, and Slovenia. A proper loan classification and provisioning system ensures credibility of the financial system that in turn restores trust and confidence in the mind of depositors. Determining what constitutes an adequate level of provisions to absorb credit losses is often subject of debate between banks and supervisors, as changes in provisioning estimate an immediate impact in bank earnings and, eventually, regulatory capital. A comparative analysis in this study between South East Europe (SEE) countries shows that countries have the regulatory measures which correspond with international standards. However, the criteria for classifying and provisioning loan portfolios depend on the prudential policies of the central banks. In the area of NPL definition, we find that almost all of the countries in the region have some type of asset classification system in place covering all types of borrowers. Non performing exposures in the region are generally defined three criteria: 90 days past due status, borrower bankruptcy, and the significant financial difficulty of the borrower. Countries with the highest rate of non-performing loans (2005-2015) are Serbia, Montenegro, Albania, while the countries with the highest percentage of coverage with provisions are: Kosovo, Macedonia and Serbia.
\end{abstract}

Keywords: loan classification, loan loss provisions, macroprudential policies, financial stability, substandard, doubtful, loss, watch, substandard

\section{INTRODUCTION}

Banks are seen as key players in the economic development of a country. Banks play their role in economic development by creating funds for investors that do not have enough resources to finance their business ideas. One of the primary roles of banks is to provide loans for their clients.
While economic growth is strongly getting rooted in the economies of Central and Eastern European Countries (CEE), development remains lower in South East European Countries (SEE). Reaiming high debts, slow regulation of labor market, strong relations with weakest economies of eurozone and lack of structured reforms in comparison with CEE 
countries, further express the lack of development in SEE countries. According to a research by International Finance Corporation (IFC, 2016) banking sector in SEE differs dramatically from the one in United States or Western Europe. Countries in the region that do not even have stock exchanges, have very limited trade, with some exceptions. This way, businesses in most of SEE countries depend on banks to ensure financing. Most of the local banks in SEE region are classical in obtaining deposits and providing loans for businesses.

Trends in quality of loans and problematic loans depend on the general economic conditions in local markets. Regarding loan quality as a serious issue in the banking system, there is a wide empirical literature that confirms interaction between macroeconomic conditions and the quality of activities. Therefore, accounting on loan losses is of special interest for banking supervisors all over the world. Loan quality is important for the financial power of the bank. This can be noted either through the item in the income statement that is Loan Loss Provision (LLP), or through the item in the balance sheet of the bank known as Loan Loss Reserves (LLR). Quagliariello (2007) emphasises that banks share provisions against profits, when they believe that loan receivers are going to fail. This is a tool they can use to regulate the value (historical) of loans, in order to reflect their true value. Provisions affect both the profit of banks and the value of the assets. Prudential banks can also use provisions to stabilize their incomes, with the passing of time lowering or increasing the flow of provisions, when their performance is worsened or improved. In the last years many banks across Europe experienced a rapid decline in quality of activities, leading towards considerable loss and lowering capital adequacy.

Rapid increase of non-performing loans (NPL) not only increased the weakness of banks towards further hits, but also limited their loan provisioning operations with wide scale consequences in the economic activity. While NPL correspond to macroeconomic conditions, such as GDP growth, results show that there are returning effects from the banking system in the real economy. More concretely, estimations suggest that the increase of NPL has a significant impact in loans (as part of GDP), in the real growth of GDP, unemployment, and inflation in upcoming periods, assessing this way the notion that a healthy and steady increase cannot have been achieved without a healthy and stable banking system. Objectives of this study are: first, to study the loan classification and provisioning system in SEE countries, and second, to compare the prudential regulation of the countries under this study. Comparison among countries in relation to classified loan and provisioning is very difficult because of differences in objective situation (actual lending environment) prevailing in the different countries. Keeping in mind the above constraint, the study has focused on prudential norms of related countries such as Albania, Bosnia and Herzegovina, Bulgaria, Croatia, Kosovo, Macedonia, Montenegro, Serbia, and Slovenia.

\section{Non-performing loans during period 2005-2015 in SEE countries}

Banking sector is considered an important source of financing for most businesses. Due to the nature of their business, commercial banks are exposed to the risk of loans not being paid by the receiver. As an after effect, development of a successful banking sector is crucial for economical growth.

Considering regional developments, an assessment of efficiency and performance of banking sector is advised, as well as continuous monitoring by the local authorities and authorized European institutions to closely assess the quality of assets, level of capitalization and restructuring.According to Berge and Boye (2007) non-performing loans serve as an important financial indicator for imbalances in the household and enterprise sectors. A big portion of non-performing loans show that many loan receivers are having problems in paying their debt. This can result in great loss of loans for banks. According to a publication of European Bank Coordination Initiative (EBCI, 2012) high reports of NPLs represent a worrying issue for some reasons. First, it can increase financial stress, especially if the provisioning from the banks is inadequate, their capital coverage is low and further increase of NPLs is on the rise. Second, high non-performing loans can reflect a deeper and general problem with debt in the household and corporate sectors. The third concern is that lingering weakness in loan portfolios becomes a drag on economic growth. Authorities in different countries use different criteria to define non-performing loans, that differ among different countries' jurisdictions. Therefore, the International Monetary Fund (IMF 2005, p.4) defines a nonperforming loan as follows: "A loan is nonperforming when payments of interest and/or principal are past due by 90 days or more, or interest payments equal to 90 days or more have been capitalized, refinanced, or delayed by agreement, or payments are less than 90 days overdue, but there are other good reasons-such as a debtor filing for bankruptcy-to doubt that payments will be made in full." Same report of IMF (2005) clarifies that after a loan is classified as non-performing, it has to remain the same until it is paid in full, as well as payments of the interest. The 90 day overdue criteria is the most common, but is not universally used, because every international comparison related to NPL requires information on national practices.

Nevertheless, clasification of loans differs in SEE countries (Tab. I). In Albania (Bank of Albania, 2016) "non-performing loans" means the total loans (principal and interest) classified as "substandard", "doubtful", "loss"and restructured according to the provisions of regulation. According to the banking legislation of the Central Bank of Bosnia and 
Herzegovina (Central bank of Bosnia and Herzegovina, 2017) banks classify assets in five categories: A Category - Performing Assets, B Category - Special mention, C Category - Sub-standard assets, D Category - Doubtful Assets, E Category- Loss. According to the banking legislation of Bosnia and Herzegovina non-performing assets represent assets, which as a rule, do not generate income. Non-performing assets are the assets' items when the principal and/or interest are due and are not collected for longer than 90 days from the day of their initially agreed maturity, i.e., when they are classified in the categories C, D and E. According to Country Report of IMF (2010) Bulgaria has four categories of credits and they are: standard, watch, nonperforming dhe loss. Non-performing loans are determined from 91 days to 180 days, while the lost loans are determined beyond 180 days. Croatia (Barisitz, 2011) defines five categories, but NPLs are seen as encompassing four of these five (categories B1, B2,
B3 and C) because the 90days + threshold already includes category $\mathrm{Bl}$ and because evidence of "partial impairment" is identified for all B categories. On the other hand, the National Bank of Serbia (Barisitz, 2011) regards nonperforming loans as loans for which the payment of either principal or interest are past due by 90 or more days or for which payments are less than 90 days overdue, if the bank assesses that the debtor's ability to repay has deteriorated. In Montenegro NPLs are considered as loans past overdue more than 90 days, but that is not the only criteria. NPLs correspond to "substandard", "doubtful", and "loss" loans.

In Macedonia and Slovenia (EBCI, 2012) NPLs cover classified claims with delays over 90 days after the maturity date. While the Central Bank of Kosovo (CBK, 2016) in non-performing loans defines the categories of doubtful and lost credits. From Tab. I we understand that the countries with number of more days overdue to classify

I: Numbers of days past due for classifying loans as:

\begin{tabular}{lccccc}
\hline \multicolumn{1}{c}{ Countries } & $\begin{array}{c}\text { Standard } \\
\text { (number of days) }\end{array}$ & Watch & Substandard & Doubtful & Loss \\
\hline Albania & $1-30$ & $31-90$ & $91-180$ & $181-365$ & $>365$ \\
Bosnia and H. & - & deri ne 90 & $90-180$ & $181-270$ & $>271$ \\
Bulgaria & $<=30$ & $31-90$ & $91-180$ (non-perform.) & $>180$ \\
Croacia & - & $90-180$ & $180-270$ & $270-365$ & $>365$ \\
Kosovo & 30 & $31-60$ & $61-90$ & $91-180$ & $>180$ \\
Macedonia & up to 31 days & $61-90$ & $121-180$ & $241-300$ & $>241$ \\
Montenegro & $<=30$ & $31-60$ & $61-270$ & $271-365$ & $>365$ \\
Serbia & $<=30$ & $31-60$ & $60-90$ & $91-180$ & $>180$ \\
Slovenia & up to 15 days & $>30$ & $30-90$ & $90-360$ & $>360$ \\
\hline
\end{tabular}

Source: World Bank, IMF, central banks (various years)

II: Criteria to classify assets as non performing ${ }^{1}$

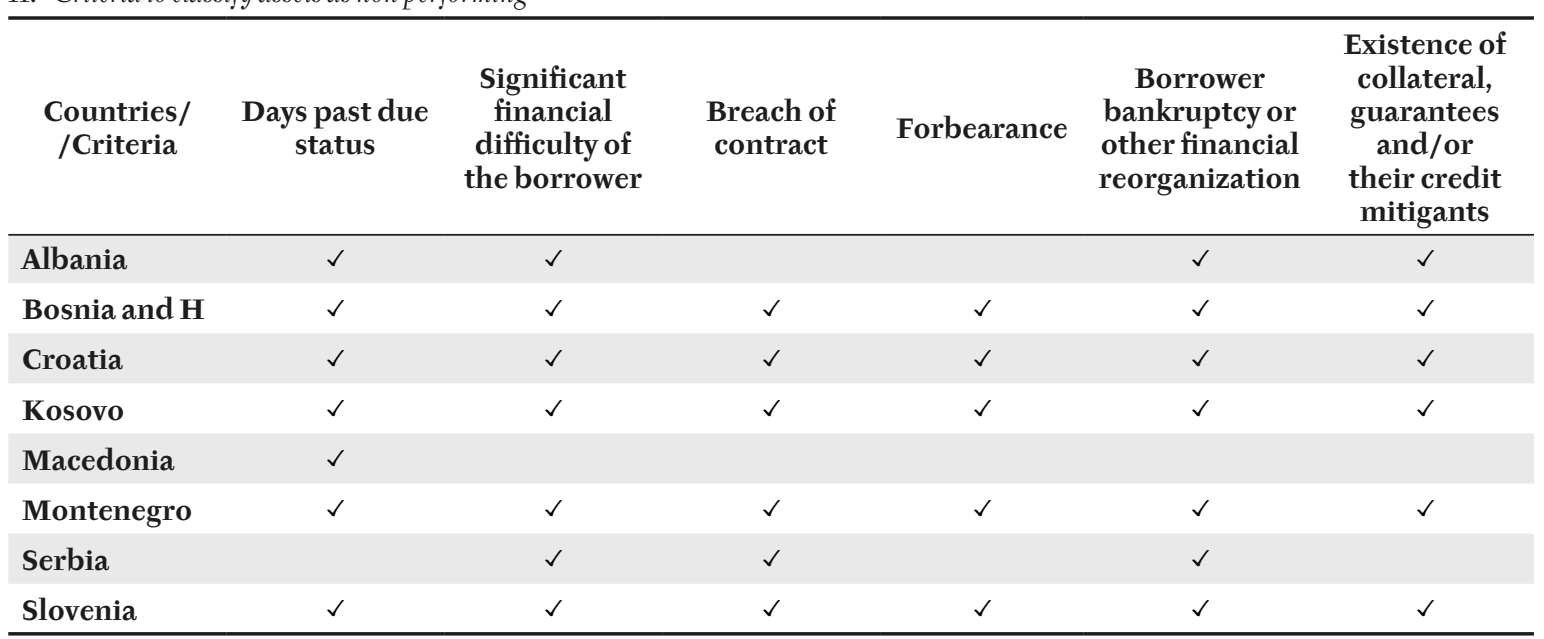

Source: Loan Classification and Loan Classification and Provisioning: Current Praktices in 26 Countries (World Bank, 2014, p.29)

1 Bulgaria recently repealed Ordinance nr 9 but it continues to exist as a reference point for banks. As this regulation is not binding, it has been excluded from the analysis in this paper. 
a loan as Loss are Croatia (365 days), Montenegro (365 days), and Albania (365 days). Croatia of all countries, does also have the longest period of loan classification, and this reflects macroeconomic conditions such as GDP, unemployment, and inflation. On the other hand, the countries with the shortest time to classify a loan as Loss are Kosovo, Bulgaria, and Serbia with 180 days each. As emphasised in the research of European Bank Coordination Initiative (EBCI, 2012) for Central European, Eastern, and South-Eastern countries, all countries responded that their NPLs definition is based on loans gross of provisions, accounts for the total, amount of defaulted outstanding loans, employs a 90 days overdue threshold, and covers non-financial corporations and private households. Where the NPL definition is based on loan classification, NPLs usually comprise the categories "substandard, "doubtful," and "lost" loans. Report emphasises that high levels of loans with problems can be a threat for the financial stability. Bank earnings suffer if there are mistakes made related to provisions, and the general financial stability is going to be threatened, with considerable portion of banking system (EBCI, 2012).

On Tab. II we can see the criteria that are taken into consideration by the countries during their classification of non-performing activities (Loan Classification and Loan Classification and
Provisioning: Current Praktices in 26 Countries, World Bank, 2014).

From this summary in Tab. II we understand that the criteria: "Days past due status", "Significant financial difficulty of the borrower", "Borrower bankruptcy or other financial reorganization" are the most common criteria used for classifying assets as non-performing. Kosovo takes into consideration all criteria to classify a non-performing loan. In the banking sector in Kosovo, exposure to loan risk continued to decrease, being reflected with a lower norm of non-performing loans compared to the total number of loans, especially in the recent years. Lower exposure towards loan risk is reflected in the flow of loans of lower categories towards the category of loans without delays. Based on the regulations of CBK on Loan Risk Management, of years 2013 and 2016 (CBK, 2013 and 2016) loans in the banking system of Kosovo are classified in three main categories: Past due loans, Classified loans, and Non-performing loans. Past due loans are defined as the loans classified in the categories of credit classification as: watch, substandard, doubtful and loss. Classified loans are defined as the loans classified in the categories of credit classification as: substandard, doubtful and loss.

Tab. III that follows, represents in percentage the participation of each loan in the available data in the Financial Stability Report for different years reported by CBK.

III: Structure of loans by classification in Kosova (\%)

\begin{tabular}{lcccccccccc}
\hline \multicolumn{1}{c}{ Loans/Years } & $\mathbf{2 0 0 8}$ & $\mathbf{2 0 0 9}$ & $\mathbf{2 0 1 0}$ & $\mathbf{2 0 1 1}$ & $\mathbf{2 0 1 2}$ & $\mathbf{2 0 1 3}$ & $\mathbf{2 0 1 4}$ & $\mathbf{2 0 1 5}$ & $\mathbf{2 0 1 6}$ \\
\hline Standard & 89.9 & 91 & 89.9 & 89.3 & 88.5 & 86.8 & 84.9 & 87.6 & 91.3 \\
\hline Watch & 5 & 3.4 & 3.1 & 2.5 & 2 & 2.2 & 3 & 2.3 & 1.9 \\
\hline Sub-standard & 1.5 & 1.7 & 2.6 & 2.3 & 3 & 3.2 & 4 & 2.9 & 1.6 \\
\hline Doubtful & 1 & 1.5 & 1.7 & 2.4 & 2.1 & 2.5 & 2 & 1.2 & 1.3 \\
\hline Loss & 2.7 & 2.4 & 2.8 & 3.5 & 4.3 & 5.2 & 6.2 & 6 & 3.9 \\
\hline Loans with problems & 5.2 & 5.6 & 7.1 & 8.2 & 9.4 & 10.9 & 12.2 & 10.1 & 6.8 \\
\hline
\end{tabular}

Source: CBK, Financial Stability Report (various reports and years)

IV: Non-performing loans (as \% of total loans)

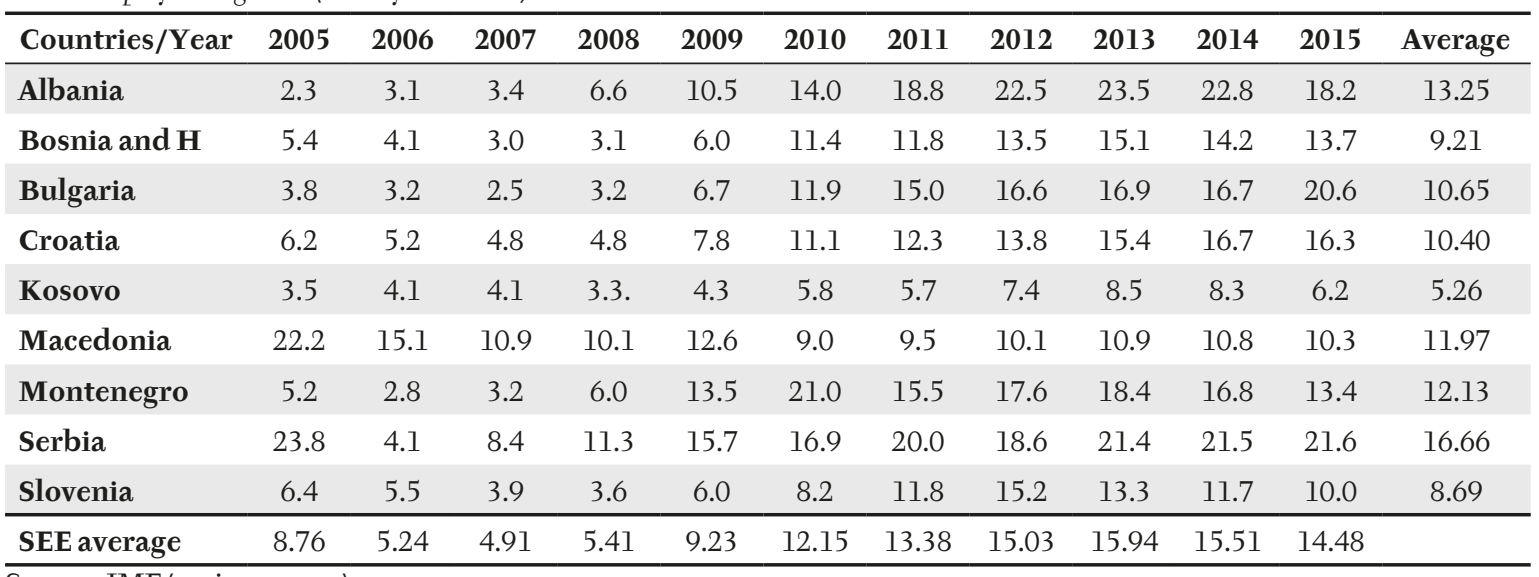

Source: IMF (various years) 
From Tab. III we understand that in the period 2008-2014 there has been a slight movement of loans from categories of higher quality, towards categories with lower quality. As a result of this, participation of loans with problems (categories: substandard, doubtful, and lost) in the total loans in the banking system, has been continuously increased since 2008 (5.2\%), until 2015 (10.1\%). Increase of NPLs is presented in the level of provisions based on the CBK regulation for loan provisioning based on classification.

Following the crisis of 2008/09, NPLs increased rapidly across SEE countries, sometimes to reach very high levels comparable to those seen in the wake of earlier financial crises. NPL problems became most acute in those countries where the economic slump was particularly deep and where the pre-crisis credit boom had been the most extreme: NPL ratios reached some $20 \%$ in Montenegro (EBCI, 2012).

Rapid increase of NPLs not only increased the weakness of banks further, but also limits their loaning operations with broader consequences for the economic activity.

High level of non-performing loans in the banking system is concerning because it shows that individuals and businesses have difficulties in paying debts, increasing the risk for the whole economic system of the country. In SEE countries during period 2005-2015, the highest increase regarding problematic loans has been registered in Serbia, Montenegro and Albania (Tab. IV). In Serbia, the percentage of non-performing loans compared to the total loans has been the highest with $23.8 \%$ in 2005, while in Albania it reached $23.5 \%$ in 2013 . Besides the fact that there has not been any hard recession in SEE countries, NPLs report in all countries reached a very high level during this period, except for Kosovo. Kosovo managed to maintain this trend in one-numbered values, and continues to have the lowest level compared to all other countries. Loan risk exposure continued to decrease, being reflected with further decrease of non-performing loans towards to all loans, in comparison to other SEE countries. Banking sector balance is almost fully denominated in euro currency, and consequently has lower exposure to the exchange risk. NPL rate of the Kosovo's banking sector, which followed a declining trend since November 2014, remains at lower level compared to the region countries. The decline of non-performing loans to total loans was impacted by the higher increase of loans and the significant improvement of credit quality (CBK, 2017). Whereas one of the factors that may have contributed in improvement to the quality of the loan portfolio sector is the fact that in recent years banks have applied tighter lending standards for the economy (CBK, 2015).

Before the global financial crisis, Macedonian economy experienced a rapid credit growth, with a low increase in non-performing loans. Non-performing loans in the banking system of the Republic of Macedonia rose since the beginning of the global crisis, but still preserved at a moderate and stable level of about $10 \%$ in the period 2010-2015. The main driver of non-performing loans is the corporate sector, with a share of around $80 \%$ in the total non-performing loans. Still, in the period 2008-2012, there was an increase in the share of non-performing loans to households (reaching the level of around 30\% of total NPLs), as a result of a drastic growth of the exposure with poorer quality. (Report on the Banking System and Banking Supervision of the Republic of Macedonia, 2008). With the slow recovery in the following years, the share of non-performing loans to households decreased, and at the end of 2015, it was on the level as before the global financial crisis. In December 2015, the NBRM amended the Decision on credit risk management, requiring from banks, by 30 June 2016, to write-off all claims that have been fully provisioned for more than two years. In addition, banks are still allowed and required to collect these claims, although they are written off (Decision on amending the Decision on credit risk management, NBRM). Consequently, at the end of 2016, mainly as a result of this measure, the share of non-performing loans was reduced to $6.6 \%$.

\section{Loan Loss Provisioning Practices in SEE countries}

Reviewing regional developments, appropriate assessment of the efficiency and performance of the banking system, continuous monitoring from local supervising authorities and authorized european institutions is further advised, to closely review the quality of assets, level of restructuring and capitalization. On every date of the balance, bank leaders are going to assess the loss they expect because of the failure. Recognition of loss happens through offering of provision for loan losses, classified as a spending account. In most countries provisions are divided as specific and general provisions.

According to Floro (2010) the decision to divide provisions depends on certain circumstances of loan risk, such as: risk of failure and macroeconomic environment (economic activity and monetary policies for example). In another research related to provisions organized by IMF, it is also emphasized that specific provisions are payments based on evidence of value loss of specific assets, while the general ones are not related to specific activities (Krueger, 2002). According to Gebhardt and NovotnyFarkas (2011) provisions for loan losses are recognized to specifically identify individual loan risk (specific provisions for loan loss). Moreover Gebhardt and Novotny-Farkas (2011) emphasize that LLPs increase the allowance for loan losses, which is presented in financial overview or as counter-asset, or as a decrease in loan value. According to the authors, allowance on loan loss is an account that includes all previous and current losses of loan loss provision. When loans are supposed to be non-refundable, they 
are considered as lost towards compensation account for loan loss, which does not affect the income. Glen and Mondragón-Vél (2011) have done research in 22 developed countries during the period 1996-2008 for more than 29000 private and public banks. This study researches the effects of business cycles (measured by GDP and norms of interest) in loan portfolio flows in commercial banks. Authors measured the loan performance with provisions on loan loss. Results show that while economic growth is the main promoter of loan portfolio flow, effects of norms of interest take the second place. Results show that the relation between LLP and economic development are going to be non-linear only under extreme economic stress, which means that increase of GDP should fall for more than 6 points in percentage (pp, in absolute terms), in order to generate an increase in loan loss provisions. Data supports non-linear effects in extreme economic contractions, more abort individual banks rather than the banking system. Besides this, low quality of loan portfolio and low capitalization of banking system are related to high levels of LLPs.

Makri and Papadatos (2014) studied the determinants of loan risk in the Greek banking system for the period
2001-2012. Authors investigated on whether loan quality can be explained with accounting and and macroeconomic factors. Results show that LLPs are positively affected by unemployment, public debt, loan loss provisions of the previous trimester, and negatively affected by capital sufficiency. According to the authors macroeconomic environment and accounting information exercise a higher impact on loan risk in banking system.

In all research it is emphasized that big financial institutions such as commercial banks, have a higher exposure towards loan risks. Loaners are exposed to loan risk when they provide loans, therefore preventive measures that banks undertake to defend themselves from loan risk, respectively from non-performing loans is the provisioning of loans. In most countries besides loan classification using the criteria of days, regulatory framework for provision classification is also clear and careful in relation to number of days delayed.

Banks classify loans into five categories, and in accordance with circumstances, provisions for each category, by applying percentages based on Tab. V.

From Tab. V we see that percentage of LLPs is significantly increased with the worsening of

V: Minimum provisioning requirements as loans become:

\begin{tabular}{|c|c|c|c|c|c|c|c|c|c|}
\hline Loans $^{2}$ & AL & $B$ and $H$. & BU & $\mathbf{K R}$ & KV & MA & MO & SE & $\begin{array}{c}\text { SL } \\
(2006-12)\end{array}$ \\
\hline $\mathbf{A}$ & $\begin{array}{l}\text { no lower } \\
\text { than } 2 \%\end{array}$ & $2 \%$ & $\mathrm{X}^{3}$ & $0.85 \%-1.2 \%$ & - & $0 \%-5 \%$ & $0 \%$ & $1 \%-2 \%$ & $0.6 \%$ \\
\hline B & $15 \%$ & $5-15 \%$ & $10 \%$ & $>30 \%$ & - & $5 \%-20 \%$ & $2 \%-7 \%$ & $5 \%-10 \%$ & $3.2 \%$ \\
\hline $\mathbf{C}$ & $40 \%$ & $16-40 \%$ & $50^{4}$ & $31 \%-70 \%$ & $20 \%$ & $20 \%-45 \%$ & $20 \%-40 \%$ & $20 \%-35 \%$ & $13.6 \%$ \\
\hline $\mathbf{E}$ & $100 \%$ & $100 \%$ & $100 \%$ & $100 \%$ & $100 \%$ & $70 \%-100 \%$ & $100 \%$ & $100 \%$ & $80.6 \%$ \\
\hline
\end{tabular}

Source: World Bank, IMF, Central Banks (various years)

VI: Provisions to non-performing loans (\%)

\begin{tabular}{lccccccccccc}
\hline Countries/Year & $\mathbf{2 0 0 6}$ & $\mathbf{2 0 0 7}$ & $\mathbf{2 0 0 8}$ & $\mathbf{2 0 0 9}$ & $\mathbf{2 0 1 0}$ & $\mathbf{2 0 1 1}$ & $\mathbf{2 0 1 2}$ & $\mathbf{2 0 1 3}$ & $\mathbf{2 0 1 4}$ & $\mathbf{2 0 1 5}$ & Average \\
\hline Albania & 56.3 & 42.5 & 42.8 & 51.3 & 52.7 & 51.8 & 55.4 & 65.2 & 67.1 & 70.8 & 55.59 \\
Bosnia and H & 39.6 & 37.2 & 37.6 & 34.5 & 43.7 & 66.3 & 65.9 & 66.7 & 69.7 & 71.2 & 53.23 \\
\hline Bulgaria & 109.9 & 100.4 & 77.1 & 58.2 & 61.4 & 59.5 & 63.0 & 65.6 & 49.4 & 48.8 & 69.32 \\
Croatia & 56.8 & 54.4 & 48.7 & 42.8 & 38.8 & 41.3 & 42.5 & 46.3 & 51.0 & 61.9 & 48.46 \\
\hline Kosovo & 240.6 & 125.6 & 128.0 & 135.1 & 135.0 & 117.2 & 117.3 & 113.2 & 116.4 & 119.3 & 134.77 \\
Macedonia & 98.3 & 114.3 & 118.1 & 69.8 & 100.7 & 104.0 & 107.1 & 103.1 & 104.6 & 108.4 & 102.84 \\
\hline Montenegro & 78.8 & 73.6 & 55.6 & 46.3 & 30.7 & 32.8 & 40.2 & 44.7 & 45.6 & 48.4 & 49.66 \\
\hline Serbia & $\ldots$ & $\ldots$. & 153.6 & 142.5 & 133.6 & 121.4 & 120.7 & 113.8 & 114.5 & 114.2 & 101.43 \\
\hline Slovenia & 84.3 & $\ldots$ & 21.1 & 23.3 & 36.9 & 40.6 & 45.3 & 59.5 & 62.9 & 66.8 & 44.06 \\
\hline SEE average & 84.96 & 60.89 & 75.84 & 67.09 & 70.39 & 70.54 & 73.03 & 75.35 & 75.69 & 78.86 & \\
\hline
\end{tabular}

Source: IMF, Financial Soundness Indicators (various years)

2 Loans categories: Standard (A), Watch (B), Sub-standard (C), Doubtful (D), Loss (E).

3 According to the bank's judgment based on previous experience.

4 Bulgaria counts only four credit categories and the percentage of 50 is for the category of non-performing loans. 
the structure of loan portfolio evaluation of banks. A significant increase in provisions for loan losses is on loan category D (doubtful) and $\mathrm{E}$ (lost).

Croatia, Albania, Montenegro, Macedonia, and Serbia are the countries with highest percentages on loan loss provisions from category D, while Bosnia and Hercegovina, Kosovo, and Slovenia have the lowest percentages in this category.

One of the indicators of financial stability realized by IMF is provisions to non-performing loans. Bank provision for non-performing loans is an indicator of the level of provisions used as a report of loan coverage.

According to World Bank report on loan classifications and provisions, reports of coverage differ through jurisdictions based on loan portfolio content (ensured and un-ensured portfolios) and provision practices of the country. The report emphasizes that the coverage indicator can go over $100 \%$.

This is explained with the fact that in these cases we have "merging of" general and specific provisions.On Tab. VI indicator on bank provisions for non-performing loans on SEE countries is presented. In general the percentage of provisions for non-performing loans has increased from 2010 and onwards.

This means that banks are capable to cover expenses that may come from the loss as a result of non-performing loans. Kosovo compared to the region regarding coverage of non-performing loans with provisions for loan loss has a percentage higher than $100 \%$ and quite a low level of NPLs, which indicates solid protection of banking system from potential loan loss. The share of NPLs in total loans of Serbia's banking sector is higher than the regional average, it should also be noted that their coverage with regulatory provisions for loan losses on balance sheet items is also the highest in the region. Such a high share resulted not only from the worsening of macroeconomic conditions during the crisis, but also from the fact that the NPL share was already high in the pre-crisis period. The increase in the share of NPLs in total loans relative to end - 2008 has been in line with the regional average. Also, NPLs, though high, do not threaten financial stability as they are fully covered by IFRS and regulatory provisions. The fact that the Serbian banking sector holds substantial provisions of liquid assets contributes to its stability, but may also be one of the reasons behind low lending activity. The high share of liquid assets carries low risks but also low returns on equity and assets (Annual Financial Stability Report, 2017). Another important factor is exchange rate. The exchange rate influences the banking sector profit which serves as a buffer against losses. The impact of the exchange rate on NPL growth and thereby on a rise in loan loss provisions is not the only channel through which the exchange rate affects capital adequacy (Annual Financial Stability Report, 2015).

\section{MATERIALS AND METHODS}

According to Milles et al., (2006) comparative research or analysis is a broad term that includes both quantitative and qualitative comparison of social entities. Social entities may be based on many lines, such as geographical or political ones in the form of cross-national or regional comparisons. The underlying goal of comparative analysis is to search for similarity and differences (Milles et al. 2006, Rubnison and Ragin, 2007). Lor (2010) counts three main comparative research designs: single-country studies, many-country (large-N) comparisons, and few-country (small-N) comparisons.In terms of the number of cases being compared, few-country comparisons are found on the continuum between single-country studies and many-country comparisons. The countries can be as few as two. Similarly, Landman (2008, p. 26) adopted a three-part division of comparative studies into "comparing many countries, comparing few countries, and single-country studies. Lor (2010) mentioned that in comparative studies we usually need either to select or group countries, or both.

Our study based on the methodology described above has been conducted by extensive review of related literatures and collections such as publications of central banks and journals. Besides this, prudential norms for loans and LLPs of Albania, Bosnia and Herzegovina, Bulgaria, Croatia, Kosovo, Macedonia, Montenegro, Serbia, Slovenia are taken from publications of Central Banks, The World Bank, International Monetary Fund, etc. After analyzing the prudential regulation of the concerned countries and international standard, a comparative study has been made to achieve a conclusion regarding the regulatory framework for loans and LLPs of SEE.

\section{RESULTS AND DISCUSSION}

Financial sector in SEE is generally healthy. Banks are active in a generally favorable entrepreneurial environment, and with a general growing macroeconomic activity. Quality of loans provided by these banks is satisfactory with acceptable indexes of loans that are not being returned in the total of loans.

In Albania, the credit risk is mitigated by the good level of provisions, although the rate of provisioning for non-performing loans has fallen. The Bank of Albania has been active in the resolution process of non-performing loans, by intensifying the collaboration with public authorities and the banking sector, to reduce the credit risk (Financial Stability Report, 2016). In recent years, the very materialization of the risk concentration has endangered the operations of several smaller banks in Bosnia and Herzegovina banking sector. In several smaller banks, the high level of non-performing loans in total loans is a result of inadequate credit policies and the poor 
management of credit risk. These banks have also higher degree of risk concentration (Financial Stability Report, 2015). In Bulgaria, banks employed various instruments such as the sale of loans, derecognition at the expense of provisions, and debt to equity swaps through established securities. This reduced the overall credit portfolio and increased the amount of non-performing loans in the banking system (Annual Report, 2015). In Croatia, despite the slight recovery of the real estate market, the consequences of the drop in prices in the last six years were observed, among other things, in the increased growth in the share of non-performing loans (Financial Stability, 2015).

In Macedonia, the improved performance of the domestic corporate sector contributed to a reduction of the growth of non-performing loans, although the credit risk arising from this sector remains the most important factor that affects the loan portfolio quality of the banking system. Also, the risks that come from the level of non-performing loans were further reduced due to the high coverage of these loans with impairment allocated for them, thus limiting the negative effects on the solvency of the banking system (Financial Stability Report, 2015). NPL trends will largely depend on the liquidity of local economy which is one of the key sources of risks in Montenegro.

The progress would be basically achieved through an increase in economic activity on a sustainable basis - through new investments that would create new job opportunities for the population, direct capital flows to Montenegro (Financial Stability Report, 2015). In Serbia, the relatively high level of NPLs, continued to hold back lending activity. The share of gross NPLs declined due to a recovery in domestic lending to corporates, as well as due to the collection, write-off, assignment and restructuring of a part of NPLs. In August 2015, the Government of the Republic of Serbia adopted the NPL Resolution Strategy, drafted by competent ministries and the NBS, to help effectively tackle the relatively high level of NPLs (Annual Financial Stability Report, 2015). Credit risk is assessed as the most significant risk to which the Slovenian banks are exposed. According to Central Bank of Slovenia the following factors will have an adverse effect on the continuing development of credit risk in the banking sector: the continuing economic crisis; the over-indebtedness of corporates whose modest operating result limit a more rapid increase in capital; the increased risk of contagion of healthy companies due to insolvency; and the diminishing creditworthiness of corporates due to the problem of the quality and liquidity of collateral in the current economic conditions (Financial Stability Review, 2013).

In Kosovo the exposure to loan risk has increased, whereas the relation of non-performing loans towards the total of loans has increased since 2009 continuously until 2014. Meanwhile in the last three years, exposure of banking system in Kosovo to loan risk has shown a decreasing tendency. A high share of NPLs negatively affects banks' risk propensity and credit growth, jeopardising banking sector profitability and posing a systemic risk (Annual Financial Stability Report, 2016, p. 8). The established provisions for non-performing loans have adversely affected the profitability of banks (Stojanov and Giuca, 2017).

Moreover, the relatively high proportion of non-performing loans impacts the decision of foreign investors, institutional depositors and ratings agencies.

\section{CONCLUSION}

Positive developments in banking systems of SEE countries during this decade have been seriously risked from year 2009 and on, when global crisis sent to a worsening of operational environment. Consequently, problematic loans have increased considerably in all countries, and paralel to this interest norms have positively responded in increasing risks. Even though high relations of coverage are going to ensure additional safety and in general are a good indicator of a healthy provisions framework, this does not mean that all NPLs are completely ensured. This means that banks are capable to cover expenses that can come from losses as a result of non-performing loans. The foregoing discussion reveals that all the countries adopt prudential regulation to reduce risk level to the commercial banks. Among the countries categories of loan are almost same. But criteria for loan classification vary from country to country.Criteria that is used almost from all countries is Days past due status. As our concerned countries are in the same region and their socio-economic conditions are almost similar, they try to follow similar prudential regulation. All the countries try to follow the international standard of loan classification and provisioning. Increase of NPLs scale during the included period is more emphasized from year 2008 and onwards, while countries with highest scale of NPLs are: Montenegro, Serbia, and Albania. However, non-performing loans remain well covered with provisions, which relativize the sector exposure to loan risk for all countries, during the same period included in the study. Countries with highest scale of LLPs coverage are: Kosovo, Macedonia, and Serbia, while there is a considerable increase of LLPs for all countries in the last three years. From the above conclusive remark the following recommendations can be made to increase the asset quality of SEE countries: Except for economic growth, the solution to the problem of NPLs would be a proactive and cooperative approach of creditors, debtors and the regulatory 
system. This kind of comprehensive approach is particularly important in the SEE region, given that any restructuring would help spur economic recovery; Also, there is the need to improve the level of investor protection in the region which could provide additional monitoring and discipline on the way bank mangers influence loan loss provision estimates; Banks should analyses potential gaps in their NPL management over the entire 'life cycle' of NPLs; To reconsiders the effectiveness of their strategies and operational arrangements to manage NPLs; Develop action plans to be prepared for discussion with their supervisory team.

\section{REFERENCES}

BANK OF ALBANIA. 2016. On Risk Management in The Activity Of Savings and Loan Associations And Their Unions. Bank of Albania. Available at: https://www.bankofalbania.org/Supervision/Regulatory_ Framework/Supervision_regulations/Regulation_No_105_On_risk_management_in_the_activity_of_ savings_and_loan_associations_and_the ir_Unions.html [Accessed:2018, September 15].

BANK OF SLOVENIA. 2015. Regulation on the assessment of credit risk losses og banks and savings banks. Official Gazette of the Republic of Slovenia, No. 96/15. Available at: https://bankaslovenije.blob.core.windows. net/uploaded/legacyfiles/SKLEP_o_ocenjevanju_izgub_iz_kreditnih_ tveganj_ANGL.pdf [Accessed: 2018, September 15].

BARISITZ, S. 2011. Nonperforming loans in CESEE-What do they comprise In: Focus on European Economic Integration. Q4/11. Vienna: OeNB, pp. 46-68.

BERGE, T. O. and BOYE, K. G. 2007. An analysis of banks" problem loans. Norges Bank Economic Bulletin, 78(2): 65-76.

BLOEM, A. M. and FREEMAN, R. 2005. The treatment of nonperforming loans. In: Issue Paper Prepared for the July 2005 Meeting of the Advisory Expert Group on National Accounts. Fondo Monetario Internacional. Available at: https://www.imf.org/external/pubs/ft/bop/2005/05-29.pdf [Accessed: 2018, September 15].

CBK. 2013. Regulation on Credit Risk Management. Central Bank of Kosovo. Available at: https://bqk kos. org/repository/docs/korniza_ligjore/english/Credit\%20Risk\%20Management\%20for\%20Banks.pdf [Accessed: 2018, September 15].

CBK. 2016. Financial Stability Report. Central Bank of Kosovo. Available at: https://bqk- kos.org/index. php?id=100\&ar=1 [Accessed: 2018, September 15].

CBK. 2016. Rregullore per menaxhimin e rrezikut kreditor. Central Bank of Kosovo. Available at: https://bqkkos.org/repository/docs/korniza_ligjore/shqip/Rregullore\%20per\%20Menaxhimin\%20e\%20Rrezikut\%20 Kredit or\%20finale.pdf [Accessed: 2018, September 15].

CBK. 2017. Regulation operational risk management. Central Bank of Kosovo. Available at: https://bqk-kos.org/ repository/docs/korniza_ligjore/english/ENRregullore\%20per\%20Menaxhimin\%20e\%20Rrezikut\%20 Kreditor\%20finale.pdf [Accessed: 2018, September 15].

CENTRAL BANK OF BOSNIA AND HERZEGOVINA. 2017. Methodology for Compilation of Financial Soundness Indicators, Sarajevo. Sarajevo: Central Bank of Bosna and Herzegovina.

EUROPEAN BANKGIN COORDINATION VIENNA INITIATIVE. 2012. Discussion in the Working Group on NPLs in Central, Eastern and South-eastern Europe. Report. Available at: https://www.imf.org/external/region/ eur/pdf/2012/030112.pdf Accessed: 2018, September 15].

FLORO, D. 2010. Loan loss provisioning and the business cycle: Does capital matter? Evidence from Philippine banks. Bank for International Settlements.

GEBHARDT, G. U. and NOVOTNY-FARKAS, Z. 2011. Mandatory IFRS adoption and accounting quality of European banks. Journal of business finance $\sigma$ accounting, 38(3-4): 289-333.

GLEN, J. and MONDRAGON-VELEZ, C. 2011. Business cycle effects on commercial bank loan portfolio performance in developing economies. Review of Development Finance, 1(2): 150-165.

HULSTER, K.,SALOMAO-GARCIA, V. and LETELIER, R. 2014. Loan Classification and Provisioning: Current Practices in 26 ECA Countries. Financial Sector Advisory Center (FinSAC) working paper series; World Bank Group, Vienna. World Bank. Available at: https://openknowledge.worldbank.org/handle/10986/21109 [Accessed: 2018, September 15].

IMF. 2002. Financial Soundness Indicators. Available at: http://data.imf.org/?sk=51B096FA-2CD2-40C2-8D090699CC1764DA [Accessed: 2018, September 15].

IMF. 2005. The Treatment of Nonperforming Loans 2015. In: Eighteenth Meeting of the IMF Committee on Balance of Payments Statistics. Washington, D.C., June 27-July 1, 2005. IMF.

IMF. 2010. Republic of Serbia: Financial Sector Assessment Program Update- Financial System Stability Assessment. Country Report No. 10/147. International Monetaray Fund. Available at: https://www.imf. org/en/Publications/CR/Issues/2016/12/31/Republic-of-Serbia-Financial-Sector- Assessment- ProgramUpdate-Financial-System-Stability-23909 [Accessed: 2018, September 15].

INETERNATIONAL FINANCE CORPORATION. 2016. Corporate Governance for Banks in Southeast Europe. Policy Brief. DC 20433. NW, Washington: International finance Corporation. 
JAEGER, J., ROUILLON, A. and ABRAHAMS, S. D. 2016. Montenegro Financial Sector Assessment Program. Technical note. Available at: https://openknowledge.worldbank.org/bitstream/handle/10986/24128/ Montenegro000FOhts000technicalOn ote.pdf?sequence=1 [Accessed: 2018, September 15].

KRUEGER, R. 2002. International standards for impairment and provisions and their implications for financial soundness indicators (FSIs). Manuscript. International Monetary Fund.

LOR, P. J. 2010. International and comparative librarianship. In: Encyclopedia of library and information sciences. $3^{\text {rd }}$ Edition. Boca Raton, FL: CRC Press., pp. 2847-2855.

MAKRI, V. and PAPADATOS, K. 2014. How accounting information and macroeconomic environment determine credit risk? Evidence from Greece. International Journal of Economic Sciences and Applied Research, 7(1): 129-143.

MILLS, M., VAN DE BUNT, G. G. and DE BRUIJN, J. 2006. Comparative research: Persistent problems and promising solutions. International Sociology, 21(5): 619-631.

NBRM. 2013. Decesion on credit risk management. National Bank of Republic Macedonia. Available at: http:// www.nbrm.mk/ns-newsarticle decision_credit_risk_2013.nspx [Accessed:2018, September 15].

QUAGLIARIELLO, M. 2007. Banks' riskiness over the business cycle: a panel analysis on Italian intermediaries. Applied Financial Economics, 17(2): 119-138.

RUBINSON, C. and RAGIN, C. C. 2007. New methods for comparative research? In: Capitalisms Compared. Emerald Group Publishing Limited, pp. 373-389.

SZTOJANOV, E. and GUCIA, R. I. 2017.(bylo 2018) Analysis of non-performing loans for banks in Central and Eastern Europe based on their ownership structure. International Journal of Economics, Commerce and Management, 5(8): 82-97.

WORLD BANK. 2015. Bosnia and Herzegovina - Financial sector assessment program: banking sector supervision core principles implementation guide technical note (English). Financial Sector Assessment Program (FSAP). Washington, D. C.: World Bank Group. 